\title{
Gambaran Status Gizi Dan Frekuensi Diare Pada Balita Usia 0 Sampai 59 Bulan Di Puskesmas Donggala Kabupaten Donggala
}

\section{Description Of Nutrition And Frequency Of Diarrhea Status In Toddlers Age 0 To 59 Months In Donggala Clinics, Donggala District}

\author{
${ }^{1}$ Elvyrah Faisal, ${ }^{1}$ Putu Candriasih, ${ }^{1}$ Ni Putu Ani Pratiwi \\ ${ }^{1}$ Poltekkes Kemenkes Palu \\ (virafaisal@yahoo.com, 08114049394)
}

\begin{abstract}
ABSTRAK
Status gizi merupakan ekspresi dari keadaan tubuh yang dipengaruhi oleh konsumsi makanan dan zat gizi. Status gizi pada balita dipengaruhi oleh faktor langsung dan faktor tidak langsung. Faktor langsung yakni asupan makanan dan penyakit. Penelitian ini bertujuan untuk mengetahui gambaran status gizi dan frekuensi diare pada balita usia 0 sampai 59 bulan di Puskesmas Donggala Kabupaten Donggala. Penelitian ini merupakan penelitian deskriptif yaitu penelitian yang dilakukan untuk melihat gambaran status gizi pada balita usia 0 sampai 59 bulan di Puskesmas Donggala Kabupaten Donggala. Populasi penelitian adalah 78 balita yang menderita diare berdasarkan gejala. Data yang diperoleh yakni data sekunder dari Puskesmas Donggala. Hasil dari penelitian ini menunjukan bahwa balita yang mengalami gizi buruk dan gizi kurang sebanyak 35,9\%, gizi lebih 7,7\% dari 78 balita. Berdasarkan $\mathrm{PB} / \mathrm{U}$ balita sangat pendek dan pendek 35,9\%, balita tinggi 7,7\%. Sedangkan berdasarkan $\mathrm{BB} / \mathrm{PB}$ balita sangat kurus dan kurus $15,4 \%$ dan tidak terdapat balita yang berstatus gizi gemuk. Frekuensi Diare berdasarkan kriteria diare dengan dehidrasi berat 16,7\%, diare dehidrasi ringan sedang $38,5 \%$, diare tanpa dehidrasi $37,2 \%$ dan disentri $7,7 \%$. Kesimpulan dari penelitian ini yaitu Status gizi balita yang mengalami diare berdasarkan indikator $\mathrm{BB} / \mathrm{U}$ dan $\mathrm{PB} / \mathrm{U}$ sebagian besar berstatus gizi normal $56,4 \%$. Sedangkan hasil dari indikator BB/PB sebagian besar balita berstatus gizi normal $(84,6 \%)$. Frekuensi diare terbanyak berdasarkan kriteria diare dengan dehidrasi ringan sedang yaitu 30 orang $(38,5 \%)$.
\end{abstract}

Kata kunci : Status Gizi, Frekuensi Diare

\begin{abstract}
Nutritional status is an expression of the state of the body that is affected by consumption of food and nutrients. Nutritional status in infants is influenced by both direct and indirect factors. The immediate factor is food intake and disease. This study aims to determine the nutritional status and frequency of diarrhea in toddlers aged 0 to 59 months at the Donggala Health Center in Donggala Regency. This research is a descriptive study that is a study conducted to see a picture of nutritional status in children aged 0 to 59 months at the Donggala Health Center in Donggala Regency. The study population was 78 toddlers suffering from symptoms based diarrhea. The data obtained are secondary data from the Donggala Health Center. The results of this study indicate that toddlers who experience malnutrition and malnutrition as much as $35.9 \%$, over $7.7 \%$ nutrition from 78 toddlers. Based on PB / $U$, toddlers are very short and $35.9 \%$ short, toddlers are $7.7 \%$ tall. Whereas based on $B B / P B$, toddlers are very thin and thin $15.4 \%$ and there are no toddlers with fat nutritional status. Frequency of diarrhea based on criteria of diarrhea with severe dehydration $16.7 \%$, mild dehydration diarrhea $38.5 \%$, diarrhea without dehydration $37.2 \%$ and dysentery $7.7 \%$. The conclusion of this study is that the nutritional status of children under five who suffer from diarrhea based on the indicators $B B / U$ and $P B / U$ mostly 56.4\% normal nutritional status. While the results of the $B B / P B$ indicators are mostly toddlers with normal nutritional status (84.6\%). The highest frequency of diarrhea based on the criteria of diarrhea with mild to moderate dehydration is 30 people (38.5\%).
\end{abstract}

Keywords : Nutritional Status, Frequency of Diarrhea

\section{PENDAHULUAN}


Menurut World Health Organization (WHO), diare adalah buang air besar (BAB) dengan konsistensi lembek hingga cair dan frekuensi $>3$ kali sehari. Menurut data WHO tahun 2012, diare adalah penyebab nomor satu kematian anak di bawah lima tahun (balita) di seluruh dunia yang mengakibatkan 842.000 kematian, 361.000 diantaranya merupakan balita.

Prevalensi gizi kurang berdasarkan BB/U menurut kabupaten/kota di Provinsi Sulawesi Tengah berdasarkan Riskesdas 2013 yaitu pada urutan pertama Kabupaten Bnggai Kepulauan sebanyak 22\%, kedua Donggala sebanyak 22,1\%, ketiga Tojo Una-Una sebanyak 21,5\% dan terakhir Parigi Mautong sebanyak $19,0 \%{ }^{1}$

Diare sering terjadi akibat infeksi saluran cerna sehingga jika hal tersebut terjadi secara terus menerus, akan mengakibatkan dehidrasi. Apabila bayi atau balita mengalami kondisi tersebut secara terus menerus, di butuhkan penggantian cairan dan elektrolit, yaitu dengan rehidrasi oral. Balita yang mengalami dehidrasi akibat diare jika tidak segera di obati maka akan berdampak dengan status gizi anak tersebut.

Pada tahun 2015 telah terjadi kejadian luar biasa (KLB) Diare sebanyak 3 kali dengan jumlah kasus sebanyak 50 kasus dan 4 kematian sehingga case fatality rate (CFR) saat kejadian luar biasa (KLB) mencapai $8 \%$. Secara Nasional case fatality rate (CFR) saat kejadian luar biasa (KLB) diharapkan $<1 \%$, sehingga bila melihat case fatality rate (CFR) saat kejadian luar biasa (KLB) Diare di Propinsi Sulawesi Tengah maka tidak memenuhi target.

Di Sulawesi Tengah tahun 2015, target penemuan kasus diare yaitu 61.561 kasus. Berdasarkan laporan bulanan program Diare menurut Kabupaten/Kota tahun 2015, jumlah kasus Diare yang ditangani di sarana kesehatan adalah sebanyak 55.211 kasus dengan persentase yaitu $89,7 \%$. Secara keseluruhan, kasus diare dominan pada jenis kelamin Perempuan $(92,2 \%)$ dari pada jenis kelamin laki-laki $(8,9 \%)^{2}$

Kejadian luar biasa (KLB) Diare terjadi di 3 Kabupaten dari 13 kabupaten/kota di Propinsi Sulawesi Tengah yaitu Kabupaten Tolitoli, Donggala, dan Banggai Laut. Kabupaten Toli-Toli merupakan kabupaten dengan jumlah penderita diare terbanyak (31 kasus) saat kejadian luar biasa (KLB) dengan Case Fatality Rate (CFR) 0. Case Fatality Rate (CFR) saat kejadian luar biasa (KLB) yang lebih dari $1 \%$ adalah Kabupaten Donggala yaitu $12 \%$ dan Kabupaten Banggai laut $30 \%$. $^{2}$

Pada tahun 2016 menurut data Dinkes Kabupaten Donggala prevalensi kasus kejadian diare meningkat di lima wilayah kerja puskesmas di Kabupaten Donggala yakni wilayah kerja puskesmas Ogoamas kecamatan Sojol utara tahun 2016 jumlah kasus 32,85\%. Puskesmas Batusuya kecamatan sindue tobata tahun 2016 jumlah kasus 60,11\%. Puskesmas Batusuya kecamatan Sindue Tambusabora pada tahun 2016 jumlah kasus 46,04\%. 
Puskesmas Donggala pada tahun 2016 jumlah kasusnya $72,30 \%$. Puskesmas Lembasada pada tahun 2016 jumlah kasus 42,27\%. ${ }^{3}$

Dari data yang di dapat di Dinkes Donggala Puskesmas yang mengalami kenaikan tinggi dari tahun 2014, 2015 ke tahun 2016 yaitu wilayah kerja Puskesmas Donggala kecamatan Banawa Tengan yaitu dari jumlah kasus pada tahun 2015 berjumlah 27,62\% meningkat ditahun 2016 menjadi 72,30\% kasus. Jadi peneliti tertarik untuk melakukan penelitian di Puskesmas Donggala. Diketahuinya gambaran status gizi dan frekuensi diare pada balita usia 0 sampai 59 bulan di Puskesmas Donggala Kabupaten Donggala.

Berdasarkan latar belakang tersebut maka peneliti tertarik untuk melakukan penelitian tentang gambaran status gizi dan frekuensi diare pada balita usia 0 sampai 59 bulan di Puskesmas Donggala Kabupaten Donggala.

\section{METODE PENELITIAN}

Penelitian ini merupakan jenis penelitian deskriptif, bertempat di Puskesmas Donggala Kabupaten Donggala dilaksanakan pada tanggal 19 sampai 22 Februari 2018. Populasi dari penelitian ini ialah semua balita yang berusia 0 sampai 59 bulan yang berobat karena diare ke Puskesmas Donggala. Sampel merupakan Total populasi yaitu balita yang berobat karena diare ke Puskesmas Donggala. Analisis data menggunakan analisis univariat dan bivariat. Data disajikan dalam bentuk tabel distribusi frekuensi disertai dengan narasi.

\section{HASIL}

a. Status Gizi Responden

Tabel 1 Distribusi Status Gizi pada balita di Puskesmas Donggala

\begin{tabular}{lcc}
\hline \multicolumn{1}{c}{ Status gizi } & f & $\%$ \\
\hline BB/U & & \\
\hline Gizi Buruk & 9 & 11,5 \\
Gizi Kurang & 19 & 24,4 \\
Gizi Baik & 44 & 56,4 \\
Gizi Lebih & 6 & 7,7 \\
\hline PB/U & & \\
\hline Sangat Pendek & 9 & 11,5 \\
Pendek & 19 & 24,4 \\
Normal & 44 & 56,4 \\
Tinggi & 6 & 7,7 \\
\hline BB/PB & & \\
\hline Sangat Kurus & 2 & 2,6 \\
Kurus & 10 & 12,8 \\
Normal & 66 & 84,6 \\
Gemuk & $\mathbf{0}$ & $\mathbf{0}$ \\
\hline Suber : Data Sekund &
\end{tabular}

Sumber : Data Sekunder, 2018

Berdasarkan Tabel 1 didapatkan bahwa frekuensi balita dengan status gizi baik berdasarkan berat badan menurut umur sejumlah 44 orang $(56,4 \%)$ dari 78 responden, frekuensi balita status gizi normal berdasarkan panjang badan menurut umur sejumlah 44 orang $(56,4 \%)$ dari 78 responden, dan frekuensi balita status gizi normal berdasarkan berat badan menurut Panjang badan sejumlah 66 orang $(84,6 \%)$ dari 78 responden.

b. Frekuensi diare

Diare adalah keadaan dimana balita mengalami gejala buang air besar yang berbentuk cair atau lunak dengan frekuensi lebih dari 3 kali dalam sehari. 
Tabel 2 Distribusi frekuensi diare pada balita di Puskesmas Donggala

\begin{tabular}{lcc}
\hline \multicolumn{1}{c}{ Katagori Diare } & $\mathrm{f}$ & $(\%)$ \\
\hline Diare dehidrasi berat & 13 & 16.7 \\
$\begin{array}{l}\text { Diare dehidrasi } \\
\text { ringan sedang }\end{array}$ & 30 & 38.5 \\
$\begin{array}{l}\text { Diare tanpa dehidrasi } \\
\text { Disentri }\end{array}$ & 29 & 37.2 \\
\multicolumn{1}{c}{ Total } & 6 & 7.7 \\
\hline
\end{tabular}

Berdasarkan Tabel 2 didapatkan bahwa frekuensi diare terbanyak yaitu diare dengan dehidrasi ringan sedang berjumlah 30 orang $(38,5 \%)$. Dan diare tanpa dehidrasi 29 orang $(37,2 \%)$.

Tabel 3 Distribusi Katagori Diare berdasarkan Usia Balita pada balita di Puskesmas Donggala

\begin{tabular}{|c|c|c|c|c|c|c|c|c|c|c|c|c|}
\hline \multirow{4}{*}{ Katagori Diare } & \multicolumn{10}{|c|}{ Katagori Usia Balita } & & \\
\hline & \multicolumn{2}{|c|}{$0-12$} & \multicolumn{2}{|c|}{$13-24$} & \multicolumn{2}{|c|}{$25-36$} & \multicolumn{2}{|c|}{$37-48$} & \multicolumn{2}{|c|}{$49-50$} & \multirow{2}{*}{\multicolumn{2}{|c|}{ Total }} \\
\hline & & & & & & & & & & & & \\
\hline & $f$ & $\%$ & $\mathrm{f}$ & $\%$ & $\mathrm{f}$ & $\%$ & $\mathrm{f}$ & $\%$ & $\mathrm{f}$ & $\%$ & $\mathrm{f}$ & $\%$ \\
\hline Diare dehidrasi berat & 4 & 30,8 & 5 & 38,5 & 2 & 15,4 & 2 & 15,4 & 0 & 0 & 13 & 100 \\
\hline $\begin{array}{l}\text { Diare dehidrasi ringan } \\
\text { sedang }\end{array}$ & 5 & 16,7 & 8 & 26,7 & 9 & 30,0 & 7 & 23,3 & 1 & 3,3 & 30 & 100 \\
\hline Diare tanpa dehidrasi & 10 & 34,5 & 13 & 44,8 & 3 & 10,3 & 3 & 10,3 & 0 & 0 & 29 & 100 \\
\hline Disentri & 1 & 16,7 & 3 & 50,0 & 1 & 16,7 & 0 & 0 & 1 & 16,7 & 6 & 100 \\
\hline Total & 20 & 25,6 & 29 & 37,2 & 15 & 19,2 & 12 & 15,4 & 2 & 2,6 & 78 & 100 \\
\hline
\end{tabular}

Sumber : Data Sekunder Terolah, 2018

Berdasarkan Tabel 3 didapatkan hasil bahwa balita yang mengalami frekuensi diare terbanyak yaitu balita yang berusia 13-24 bulan 29 balita $(37,2 \%)$.

\section{PEMBAHASAN}

Masalah gizi buruk dan gizi kurang nampaknya belum bisa teratasi dengan baik dalam sekala internasional maupun nasional, tercatat 101 juta anak di dunia dibawah lima tahun menderita kekurangan gizi, balita yang termasuk gizi kurang mempunyai resiko meninggal lebih tinggi dibandingkan balita yang gizinya baik ${ }^{4}$. Masalah gizi kurang pada balita secara langsung disebabkan oleh anak tidak mendapatkan asupan makanan yang cukup yang mengandung gizi seimbang. ${ }^{5}$ Gizi kurang juga diakibatkan oleh adanya infeksi pada balita. Infeksi ini menganggu metabolisme, keseimbangan hormone dan fungsi imunitas. ${ }^{6}$

Berdasarkan data yang diperoleh dari Puskesmas Donggala, terdapat tiga kategori diare yaitu katagori pertama dehidrasi, yang termasuk dalam kelompok dehidrasi yaitu diare dengan dehidrasi berat, diare dengan dehidrasi ringan sedang, diare tanpa dehidrasi. Katagori yang kedua yaitu diare yang > 14 hari yakni diare persisten berat dan diare persisten. Sedangkan katagori ketiga diare bercampur darah atau disentri.

Berdasarkan hasil penelitian frekuensi tertinggi yaitu balita mengalami diare dengan dehidrasi ringan sedang sebanyak 
30 orang $(38,5 \%)$. Dan kelompok usia yang paling banyak mengalami diare yaitu 13-24 bulan 29 orang. Pada usia 13-24 bulan balita sudah sudah bisa bermain sendiri dan sudah mulai terpapar makanan dari luar rumah. Pada usia tersebut balita lebih suka mengonsumsi jajanan di luar rumah mengikuti temantemannya, padahal pengolahan dan penyajian makanan tersebut kemungkinan kurang hyigenis sehingga anak balita mudah terkena diare.

Balita dengan status gizi buruk cenderung lebih mudah terkena diare, dikarenakan sistem imun pada anak balita gizi buruk mengalami penurunan. Status gizi kurang mempunyai peluang yang lebih besar untuk menderita diare, sedangkan balita dengan status gizi baik mempunyai peluang yang lebih kecil untuk menderita diare. ${ }^{7}$

Adapun penyebab lain dari terjadinya diare pada balita yakni pendidikan orang tua. Salah satu teori menyebutkan bahwa pada umumnya makin tinggi pendidikan seseorang maka makin baik pula pengetahuannya dan makin mudah menerima informasi. Pendidikan yang terbatas menunjukan sikap masa bodo, sulit berkomunikasi dengan petugas dan kurang hormat. $^{8}$

Hasil penelitian menunjukan semakin baik tingkat pendidikan orang tua maka semakin baik status gizi dan penangan diare pada anak.

\section{KESIMPULAN DAN SARAN}

Status gizi balita yang mengalami diare berdasarkan indikator $\mathrm{BB} / \mathrm{U}$ dan $\mathrm{PB} / \mathrm{U}$ sebagian besar berstatus gizi normal $56,4 \%$. Sedangkan hasil dari indikator $\mathrm{BB} / \mathrm{PB}$ sebagian besar balita berstatus gizi normal $(84,6 \%)$. Frekuensi diare terbanyak berdasarkan kriteria diare dengan dehidrasi ringan sedang yaitu 30 orang $(38,5 \%)$. Disarankan agar orangtua memperhatikan aktifitas dan pola makan balita.

\section{UCAPAN TERIMA KASIH}

Ucapan terima kasih diberikan kepada 1) Bapak Nasrul, SKM., M.Kes selaku Direktur Politeknik Kesehatan Kemenkes Palu, 2) Bupati Donggala, 3) Dinas Kesehatan Provinsi Sulawesi Tengah

\section{DAFTAR PUSTAKA}

1. Badan Penelitian dan Pengembangan Kesehatan. Riset Kesehatan Dasar (RISKESDAS) 2013. Lap Nas 2013. 2013;1-384.

2. Dinkes Prov Sulawesi Tengah. Profil Kesehatan Provinsi Sulawesi Tengah 2015. 2015.

3. Dinas kesehatan. Profil Kesehatan Provinsi Sulawesi Tenga 2015. 2015;

4. UNICEF. Improving child nutrition: The achievable imperative for global progress. Division of Communication, UNICEF. 2013.

5. Wong, L D. Buku Ajar Keperawatan Pediatrik. 6th ed. Jakarta: EGC; 2014.

6. Belaynew W BG. Assessment of Factors Associated with Malnutrition among Under Five Years Age Children at Machakel Woreda, Northwest Ethiopia: A Case Control Study. J Nutr Food Sci. 2014;04(01):1-7.

7. Zulkifli. Analisis Faktor-Faktor yang Berhubungan dengan Kejadian Diare untuk Menentukan Kebijakan Penanggulangan Diare di Wilayah Kerja Puskesmas Kecamatan Mutiara 
Kabupaten Pidie Tahun 2003. e- Reporitory USU. 2003;

8. Wawan, Dew. Teori dan Pengukuran
Pengetahuan, Sikap dan Prilaku Manusi. Yogyakarta: Nuha Medika; 2010. 